\title{
Defending Sovereignty without Collaboration: Vichy and the Italian Fascist Threats of
}

1940-42

\begin{abstract}
This article asks how Vichy sought to defend French sovereignty against Italian threats across those unoccupied areas of France and its colonial empire which were covered by the Italian armistice between June 1940 and November 1942. It suggests that while Vichy's response to German violations of French sovereignty was limited by its policy of collaboration, no such constraints were in place when it came to Italian interventions. Despite this, however, the defence of French sovereignty against Italian threats was not a straightforward story of defiance. Opposing Italian actions in one policy domain in one territory had to be weighed against the potential repercussions in another policy domain in another territory. It also had to be calibrated with the implications for French relations with Berlin. The Italian dimension to Vichy's actions therefore suggests that the biggest challenge in negotiations was not Vichy's desire to defend its sovereign status so much as the lure of collaboration.
\end{abstract}


The Vichy government's belief that defending French sovereignty required collaboration lay at the heart of its seemingly paradoxical political and ideological outlook between 1940 and 1944. A broad consensus has emerged among historians that Vichy regarded sovereignty to be so critically important that it was prepared and indeed willing to take significant measures to defend it, engaging in ever deeper collaboration with Berlin and making ever more concessions. ${ }^{1}$ In the striking words of Marc-Olivier Baruch, sovereignty became an 'obsession', such that, compromise by compromise, it 'ended in the complete vassalage of the French state to its Nazi victor'. ${ }^{2}$ When it came to Vichy’s dealings with Fascist Italy, however, no sustained policy of collaboration resulted from its defence of sovereignty, nor did the French government become drawn into making increasing concessions. Despite facing multiple Italian threats to French sovereignty, Vichy's response was neither one of unalloyed resistance nor was it one of unyielding defiance.

The aim of this article is to explore why Vichy's attempts to defend French sovereignty against Italian infringements led it neither to collaboration nor resistance nor even some destination in between. Focusing upon the unoccupied areas of France and its colonial empire under the Italian armistice authorities' jurisdiction between June 1940 and November 1942, it argues that French responses were rather multi-dimensional and multi-directional. After the defeat of June 1940, the Vichy government placed the protection of French sovereignty at the heart of its self-justification, claiming to be the only true defender of France and its colonies. Yet far from protecting the country, historians have found that Vichy's actions were selfinterested and its rationale spurious. As Robert Paxton has suggested, seeking above all to assure its own survival in order to advance its ideological agenda, Vichy attached a primary significance to the preservation of the state and its authority. ${ }^{3}$ According to Robert Frank, retaining control over the French colonial empire and naval fleet became an end in itself, 
being driven by the sole objective of maintaining the illusion of independence. ${ }^{4}$ Philippe Burrin, meanwhile, argues that Vichy strove to re-establish administrative sovereignty in relation to Germany by adapting its policies to those being imposed by Berlin. ${ }^{5}$ Marc-Olivier Baruch goes still further, suggesting that having based its claims of legitimacy on the maintenance of national sovereignty, Vichy was caught in a 'trap' of its own making, in which the line between 'serving in the face of the enemy' and 'serving the enemy' became increasingly blurred. ${ }^{6}$ Yet while there may be some agreement among historians about Vichy's responses to German infringements upon French sovereignty, to date there has been little analysis of its responses to Italian infringements. If the two elements of French policy were distinct, they were nevertheless tightly connected. Violations of French sovereignty were a problem common to Vichy's dealings with both Axis governments, but the answers they sought to these violations were not necessarily the same. The reasons that Vichy responded differently to Italian actions therefore have wider implications for historians' understanding of its actions in relation to Germany and its policy of collaboration more broadly.

Italian policies posed a distinct but nonetheless significant threat to French administrative, territorial, security, and judicial sovereignty. The threat emerged initially from disputes over the size of the French armistice army in North Africa, but above all it was the actions of the Italian control commissions in south-eastern France, Corsica, North Africa, and the Levant that represented the greatest and most immediate danger. Initially relatively small in number and ostensibly present to ensure the implementation of the armistice terms, the commissions soon expanded their activities, increasingly chipping away at French sovereignty. The Italian government's determination to pursue its territorial and political ambitions combined with its weaker position gave it a greater appetite for breaching the armistice than the German 
government. Frustrated at the terms themselves as well as their prolonged application, Italian armistice officials sought to engage directly with local populations, stirring up hostility to French authority, while advancing hostile propaganda and espionage. Yet while the French ability to check German violations of the armistice was limited by the political imperatives of collaboration, no such constraints were in place when it came to Italian actions. Because it did not accept Italian claims of victory and because it envisioned a post-war Europe led by Germany, the trajectory of Vichy's relations with Rome ran counter to its relations with Berlin. Far from moving towards ever deeper collaboration with Rome, Vichy moved further and further away from it.

Despite this, however, the defence of French sovereignty against Italian infringements was not a straightforward story of defiance. This was primarily due to the differing approaches and roles played by the French delegation to the Italian Armistice Commission, the Vichy government, and local and colonial authorities. There has been a tendency in some memoirs and in some of the scholarship to present the French armistice delegations at Wiesbaden (DFCAA) and Turin (DFCIA) as having been not just at the frontline of the attempts to preserve French sovereignty but as having engaged in a kind of resistance. ${ }^{7}$ Indeed, General Vernoux described the work of the DFCAA as being to 'combat or protest' against any contravention of the armistice terms. ${ }^{8}$ His argument is echoed by the historian Romain Rainero, who characterizes the work of the DFCIA as a 'tenacious, often victorious, struggle against Fascist ambitions and claims', amounting to 'silent resistance'. ${ }^{9}$ It was only the constraints imposed by Vichy's political agenda that prevented them from going further, they suggest, limiting French officials to 'passive resistance' in the words of Vernoux, and inhibiting the DFCIA's calls for 'all-out resistance', according to Rainero. ${ }^{10}$ 
The problem was that any such 'resistance' went only so far as opposing violations of the armistice terms. It did not extend to any active defence of French sovereignty. Vichy, the DFCIA, and the local authorities faced simultaneous challenges on numerous fronts. The decision to oppose Italian actions in one policy domain in one territory had to be weighed against the potential repercussions in another policy domain in another territory. Decisions such as these also had to weigh the implications for French relations with the Germans. The Vichy government's differing policies towards the two Axis governments and the ways in which it sought to play one against the other meant that it sometimes found itself countermanding the attempts by the armistice delegations or the colonial authorities to defend French sovereignty.

This article therefore advances an alternative interpretation to Robert Paxton's argument that 'Vichy's sovereignty was a negotiating liability rather than a negotiating asset'. ${ }^{11}$ For Paxton, the French government's determination to survive meant that it may have yielded more for Berlin than if France had been under total German occupation and ruled by a Gauleiter. This was because ultimately, Vichy was 'continually repurchasing its shadow sovereignty at a higher and higher price'. ${ }^{12}$ If Italian Fascist ambitions threatened the territorial integrity of France and its colonial empire, the survival of the Vichy regime was not, by contrast, dependent upon any kind of transaction with Rome. Without a framework of collaboration with Rome, there was not the same movement towards collusion as there was with the Nazis. The Italian dimension to Vichy's actions therefore suggests that it was not so much sovereignty in itself that was a negotiating liability as the lure of collaboration. 
The first section of this article explores the implications of the June 1940 armistice terms for French sovereignty. The second section looks at Vichy's efforts to protect French North Africa against Italian threats by seeking to increase the size of the armistice army. The third section moves on to explore how the French authorities responded to the actions of the Italian control commissions in metropolitan France, North Africa, and the Levant. The final section examines Vichy's complex negotiations between Italian and German policies on the Jews and their implications for French sovereignty.

The assets left at the disposal of the Vichy government following the June 1940 armistices comprised the French colonial empire, the naval fleet, and the unoccupied zone. They remained under French authority and lay at the core of Vichy's claims of sovereignty. Combined, they allowed France to retain a global significance and gave the government tools with which to bargain with the Axis. However, Vichy did not explicitly conceive of sovereignty as an asset. In part, this was because the June 1940 terms treated the idea of sovereignty as something subjective and intangible. This section therefore begins by exploring how the armistice negotiators conceived of sovereignty, asking how each party assessed the basis and origin of sovereignty, and where they considered it to reside. It then takes the analysis a stage further, suggesting that Vichy regarded French sovereignty in relation to the Italian armistice differently to how they saw their sovereignty in relation to the German armistice. Sovereignty was thus not absolute but relative and contingent upon political considerations about power, levels of threat, and the wider war. 
The French determination to defend their sovereignty from the Italians began with the armistice negotiations of 21-24 June 1940. This determination was rooted in accusations of betrayal following Mussolini's declaration of war on 10 June and was aggravated by the poor performance of the Italian army in the Alps. As a consequence, neither the French government nor the French armed forces accepted that Rome had any right to claim the spoils of victory. Believing that that the German and Italian armistices would be negotiated together and that the Italian terms would include a significant occupation zone and even territorial annexations, the French delegation arrived at Rethondes determined to oppose any such demands. Indeed, while they accepted the German terms as the unfortunate but justified consequence of an overwhelming military defeat, General Huntziger insisted that France would not be 'dishonoured' by punitive Italian conditions because 'although Italy had declared war on France, she had not waged war on France'. ${ }^{13}$ To the surprise of the French, under pressure from Hitler and in the belief that peace terms would follow a rapid British collapse, Mussolini agreed to temper his demands. ${ }^{14}$

Many of the Italian armistice terms paralleled those imposed by Germany. The demands included the disarmament of French troops and the navy, the demilitarization of naval bases and fortifications, the liberation of Italian prisoners of war, and agreeing not to engage in any activities harmful to Italy. What made the proposals palatable to French negotiators, however, was that they gave Italy only a small zone of occupation covering 841 square kilometres around Menton and the mountains of Savoie and inhabited by 28,523 people, compared with a German zone that spanned 304,368 square kilometres inhabited by 29 million people. And whereas France had to pay German occupation costs of 400 million francs per day, the Italian 
armistice did not impose any such demands. ${ }^{15}$ In the view of the French government, the impact of the Italian armistice upon French sovereignty was therefore limited.

From there began the divergence between French and Axis interpretations of the armistice terms. Vichy understood them as recognizing the French government's sovereignty over the whole country, including the occupied zones. ${ }^{16}$ It held the view that the only constraints upon its exercise of sovereignty were those that had been explicitly stated. By contrast, the Italian government took the view that French sovereignty was restricted across all areas other than where it was explicitly guaranteed. ${ }^{17}$ Under the terms of the Wiesbaden accords of 29 June 1940, the Axis governments agreed that the Italian Armistice Commission would oversee the implementation of the Italian terms in the Italian zone of occupation, as well as in the unoccupied areas of south-eastern France, Corsica, French North Africa, Syria, Lebanon, and French Somaliland. The German Armistice Commission was to oversee the implementation of the German terms across the rest of the free zone as well as in the German zones of occupation. It was in the unoccupied areas of France and the French colonial empire prior to November 1942 that the battles over sovereignty were to rage most fiercely, with Vichy determined to uphold its power and the Axis armistice authorities determined to extend theirs.

If the armistice terms gave Berlin greater control over France than Rome, Fascist territorial claims meant that in a different but no less troubling way, the dangers that continued to loom over the country and its colonial empire were Italian as well as German. As early as August 1940, French officials cautioned that having failed to achieve its ambitions in the armistice negotiations, Rome was purposely stoking tensions to 'create an alibi' for seizing territory in the future. ${ }^{18}$ Two months later, the secretary-general of the Ministry of Foreign Affairs 
warned that the weakness of Italy's position gave its government a greater hunger for exploiting the French defeat than was the case with Germany. ${ }^{19}$ The French assessment had scarcely changed by November $1942 .{ }^{20}$ Throughout the period under question, Vichy was keenly aware that the inferior status of the Italian government made it a more volatile threat to French sovereignty. As a consequence, whereas Rome believed that it had the legal and political right to infringe French sovereignty, without the incentive of collaboration and facing threats to France's territorial integrity, Vichy adopted a more intransigent position than with Germany. It considered Rome to have neither the legal right nor the political justification to breach French sovereignty.

In the months following the armistice, Pierre Laval sought to use his pre-war connections to appeal for clemency from Rome. His efforts came to nothing, however, as did those of Vichy's foreign minister, Paul Baudouin. ${ }^{21}$ Determined to assert Italy's status as a victor alongside Germany, over the summer and autumn of 1940, Mussolini systematically rejected Vichy's attempts to construct a new relationship of collaboration. The impasse contrasted starkly with the progress Vichy appeared to be making with Berlin. Thus while the French government was able to announce a new policy of collaboration with the Germans following the Montoire meetings of 24 October 1940, there were no such developments with the Italians. With no Italian equivalent of the German ambassador Otto Abetz to fuel delusions about collaboration, and no realistic prospect of the final peace terms being determined by Mussolini, there was little incentive for Vichy to acquiesce in the steady erosion of French sovereignty as it did with Germany. The relatively moderate terms of the Italian armistice brought fewer impositions and therefore less scope for functionaries to enact Fascist policies as though they were their own. French responses to Italian demands were therefore driven by quite different imperatives to those that compelled officials first to implement and then to 
anticipate German demands under a misguided belief that in so doing, they were preserving French sovereignty. ${ }^{22}$

\section{II}

From the outset, Vichy regarded retaining its sovereignty over the politically and strategically significant French colonial empire as a priority. Indeed, with the status of France considerably weakened by the defeat, Vichy became, in the words of Martin Thomas, 'an imperial rather than continental power'. ${ }^{23}$ The French government was therefore determined to oppose any threats resulting from Italian action, especially in the Mediterranean region, which was the subject of Fascist expansionist ambitions. ${ }^{24}$ The problem was that the June 1940 terms permitted Vichy to maintain an armistice army of only 100,000 men, leaving its colonies in North Africa vulnerable to external and internal menaces. According to Paxton, the process by which Vichy managed to secure an increase in the numbers of French forces involved conceding the arrival of German control commissions in North Africa. ${ }^{25}$ For Rainero, Vichy's attempts to gain concessions on the armistice army marked a turning-point in the 'resistance' of the DFCIA as it turned German support for French neutrality into a weapon with which to oppose Italian threats. ${ }^{26}$ While their arguments may differ, the corollary to Paxton and Rainero's argument is that the price of protecting French sovereignty against the Italians was deeper collaboration with the Germans. However, further examination of the actions of the French delegations at Wiesbaden and Turin, as well as the interventions of ministers in Vichy, suggests a different picture. 
The initial French strategy was to cloak their desire to defend sovereignty from the Italians with the claim that they needed to be able to resist the British. Having impressed the Axis with a spirited defence against the British attack on Mers-el-Kébir in early July 1940, Huntziger seized the opportunity to request an increase in the size of the armistice army to 150,000 men. ${ }^{27}$ While Berlin ostensibly supported the idea of French forces being deployed for such purposes, the head of the German Armistice Commission, General von Stülpnagel, warned Huntziger that the Germans and Italians remained suspicious about what they saw as 'measures taken by France to conserve its sovereignty'. ${ }^{28}$ It took the French defence of Dakar against British and Gaullist forces on 20 September 1940 to convince the German government finally to concede the expansion of the armistice army. ${ }^{29}$ By contrast, Rome remained vehemently opposed to any increase, seeing the French forces as a direct threat to Italian interests in North Africa. The Italian Armistice Commission (CIAF) demanded that French forces should be limited to just 30,000 men in North Africa, a figure that Vichy later decried as 'ridiculously low'. 30

It was against this backdrop that, according to Rainero, the DFCIA president Admiral Duplat became a driving force in using German support to oppose Italian threats to French sovereignty. Rainero suggests that Duplat asked Huntziger to appeal to the Chief of Staff, Marshal Badoglio, directly by letter on 16 September and that this led to a shift in the Italian position. ${ }^{31}$ However, the records of the German Armistice Commission suggest that the initiative came from Huntziger, first as head of the DFCAA then as War Minister, and that any German involvement was negligible. ${ }^{32}$ In correspondence and meetings with von Stülpnagel on 5 and 12 September 1940, Huntziger argued that Italian demands to reduce the armistice army threatened a general crisis of disorder across North Africa and the Levant. ${ }^{33}$ Yet despite these pleas, there is no direct evidence that any German intervention on the 
French behalf lay behind Badoglio's decision to allow a temporary increase in the armistice army in North Africa. ${ }^{34}$ Nor, by extension, can it be argued that the episode resulted in further French collaboration with the Germans. In his correspondence with Huntziger, Badoglio indicated that his decision to take a more conciliatory approach to French demands came from a hope of gaining a goodwill gesture from Vichy on the caches of weapons being hidden by the armistice army and the ongoing economic negotiations between the two governments. ${ }^{35}$ Contrary to Rainero's suggestion that the 'evocation of German generosity towards Vichy's neutrality [...] was an important discovery in the arsenal of the resistance of the French delegation to Italian claims', Badoglio made no allusion to the German position on French neutrality in the war, either explicitly or implicitly. ${ }^{36}$ The episode therefore did not mark a critical turning-point in the DFCIA's use of German support against Italian threats to French sovereignty.

The significance of Huntziger's intervention on 16 September 1940 was rather in how he played Badoglio's sympathy towards France against the intransigence of the head of the CIAF, General Pintor. Throughout his letter to Badoglio, Huntziger emphasized his high regard for the Italian marshal, writing with warmth and respect and even conveying Pétain's regards. He assured Badoglio of the French government's 'loyal' commitment to implementing the armistice and gave his assurance 'as a soldier' that the French forces in North Africa and the Levant would solely be used to defend against the threat from the British and from internal 'dissidence' and would not harm Italian interests. ${ }^{37}$ In other words, it was Huntziger's diplomacy rather than the DFCIA's 'resistance' that helped bring the concessions. 
For Robert Paxton, the expansion of the armistice army came not out of any German support for French neutrality but in return for Vichy agreeing to the arrival of German control commissions in North Africa. ${ }^{38}$ The suggestion that Vichy took a calculated risk by acquiescing to the German presence would seem to be supported by Laval's insistence to the American Chargé d'Affaires that Berlin had no colonial aspirations over North Africa ${ }^{39}$ It would also seem to be supported by Laval's manoeuvres to gain German protection of the French colonial empire against Italian threats in a meeting with General Warlimont on 10 December $1940 .{ }^{40}$ However, the arrival of German control commissions in North Africa was not a consequence of any kind of deal between Berlin and Vichy. It was rather the consequence of German strategic calculations and was imposed on the French government. Within less than three months of the armistices being signed, German officials had reached the conclusion that the Italians were not up to the task of holding back the British in the Middle East or of maintaining control over French activities in North Africa. ${ }^{41}$ On 5 October 1940, they informed their Italian counterparts of their intention to introduce mixed GermanItalian control commissions to West and Equatorial Africa, including Morocco. ${ }^{42}$ It was only in early January 1941 that German officials notified the head of the DFCAA, General Doyen. Far from there having been collusion between the French and German governments, Doyen expressed his 'profound surprise' at the development. ${ }^{43}$ In other words, rather than having chosen to trade the armistice army's ability to defend French sovereignty against the Italians for greater collaboration with the Germans, Vichy had merely been constrained to lose further sovereignty to the German control commissions.

It is far from clear that Berlin linked the strengthening of the armistice army with the need to introduce a German presence to the control commissions in North Africa. However, if such a connection did come into play, it would imply that although the German government 
considered the French forces to have a useful function in North Africa, it continued to be suspicious of them. Indeed, the Germans might have lacked confidence in the Italians, but they remained firm allies. In mid-February 1941, Doyen asked General Vogl whether the difficulties facing Italian forces in Tripoli had led to a cooling in German support for increasing the size of the armistice army in North Africa. ${ }^{44}$ With Rommel's Afrika Korps having to be dispatched to help stop an onslaught from the British, the implication was that the Germans did not wish to see the balance tip too far in the French favour against a weakened Italian military presence in the region. Vogl rejected French claims that the Germans were 'mistrustful' of the French armed forces, but conceded that that they remained 'wary' of them. ${ }^{45}$

That did not, of course, mean that French officials did not attempt to seek recourse from the Germans against Italian demands or to play the two armistice commissions against one another. Having initially been opposed to the arrival of the German control commissions in North Africa, Doyen sought to gain favour by telling Vogl that he welcomed their presence over that of the Italians. ${ }^{46}$ French armistice officials found that often their German counterparts shared their frustrations about the Italians. This rapport, combined with Vichy's willing engagement in collaboration and Berlin's support for the French defence of North Africa, presented multiple opportunities to gain concessions from the Germans at the expense of the Italians. Indeed, in his account of his experiences at Wiesbaden, General Vernoux argued that unlike the Italians, German officials tended to trust the French and to accede to their demands. ${ }^{47}$ French requests for German intervention therefore ranged from matters related to Italian petrol usage to seeking assistance in reducing in the numbers of Italian officials stationed in Morocco. ${ }^{48}$ However, there were limits to how much this strategy could achieve. Vernoux also acknowledged that attempts to exploit the divisions between 
Wiesbaden and Turin often failed, with the "two commissions rapidly finding grounds for agreement to present us with a united front'. ${ }^{49}$

III

If the dispute over the armistice army signalled the potential danger from Italian territorial ambitions in North Africa, this section suggests that it was the day-to-day actions of the Italian control commissions that most directly threatened French sovereignty. While the German control commissions also sought to extend their activities beyond what was permitted by the terms of the armistice, the Italians were more overt and were driven by greater desperation. Having gained relatively little from the armistice and frustrated at its extended application, Italian officials sought to realize the Fascist government's ambitions through direct encroachments upon French sovereignty on the one hand and through subversion and espionage on the other.

The first step in the strategy of the Italian control commissions was to establish a firm foothold in the areas under their jurisdiction. This involved increasing their numbers beyond the agreed limits. Thus in Corsica, despite work to implement the armistice having been completed by March 1941, Italian officials kept arriving, increasing from thirty-seven in September 1940 to fifty-one by April $1941 .^{50}$ It was in North Africa that the numbers of Italian armistice officials caused the greatest concern, however. By mid-January 1941, the Italian contingent had swelled to 151 officers and functionaries and 178 soldiers. ${ }^{51}$ When 
German armistice officials were added, the numbers reached 652 in May 1941, causing General Weygand to denounce them as nothing less than a 'battalion of propaganda and antiFrench action' ${ }^{52}$

It was not merely the numbers of Italian armistice officials that posed a threat to the French authorities; it was their composition as well. The Italian government used the control commissions as a cover for the systematic reintroduction of former consular agents. Because France and Italy were in a state of armistice rather than at peace, Italian consulates were not permitted to reopen in metropolitan France or in the French colonies after June 1940. By claiming that staff were working for the control commissions, however, Rome was able to return its former consuls to Grenoble, Nice, Modane, Annecy, Marseille, Gap, Cannes, Bastia, and Ajaccio. ${ }^{53}$ In North Africa, the former Italian consul generals for Rabat and Casablanca along with several of their staff returned, almost the entire pre-war consular corps returned to Tunis, and many of the staff from the Italian consulate returned to Algiers. ${ }^{54}$ Many had had a history of engaging in propaganda and espionage activities in the build-up to war, being well-known to police and to local communities. ${ }^{55}$ Their reappearance under the thinnest of pretexts therefore not only undermined French sovereignty but directly threatened French security as well.

The Italian control commissions sought to divide and destabilize communities and to threaten French authority. In so doing, they fuelled French fears that they were really preparing the ground for future occupation and even annexation. ${ }^{56}$ The control commissions openly engaged in surveillance and infiltration, monitoring public opinion and economic activity. ${ }^{57}$ More significantly, however, they worked to establish contacts with local Italian citizens to stir up discontent and hostility towards the French authorities. ${ }^{58}$ Under instructions from 
Rome, they summoned Italian residents directly to their offices, questioning them on their loyalty to Italy and offering to help repatriate those who might be useful to the Italian war economy or who might serve in the Italian army. ${ }^{59}$ The pool of potential recruits was enormous. Over 900,000 Italian citizens were resident in France and Corsica in 1939, with a further 126,000 in North Africa, mainly concentrated in Tunisia. ${ }^{60}$

The difficulties this posed were quite unlike anything in Vichy's dealings with the German control commissions. Not only were there significantly more Italian citizens than Germans living in France and its colonies during the war, but Italian officials construed the armistice in ways that sought to constrain French authority over them as well. Giving the terms of Article 21 on Prisoners-of-War the widest possible interpretation, they insisted that the French government could neither prevent them from making direct contact with Italian citizens nor impose any restrictions upon them. If many Italians remained loyal to France, having often migrated precisely to escape Fascism, the French authorities could not take their continued commitment for granted. Indeed, Vichy saw the control commissions' contacts with Italian citizens as not merely a challenge to French sovereignty but as a tangible security threat. The problem was that having been instructed by Vichy to monitor and control the activities of the armistice commissions, police soon realized that the task of regulating contacts between Italian officials and Italian citizens was enormous. Up to three hundred people queued to meet members of the control commission in Nice every day in August $1940{ }^{61}$ Three months later, the numbers had scarcely diminished, with up to two hundred Italian visitors arriving per day, often attracted by the offer of a free meal. ${ }^{62}$ 
It was only after a serious attack against General Boselli, the head of the Italian control commission in Algiers, that police were able to gain a greater command of the situation by introducing tighter surveillance and protection. ${ }^{63}$ Vichy ordered police to monitor all those who visited the control commissions, checking identity papers, verifying vehicle registrations, and subjecting Italian officials to virtual 'house arrest' ${ }^{64}$ However, monitoring and surveillance alone were no panacea for the daily Italian encroachments upon French security. Even where the French authorities discovered clear breaches of the armistice terms, they were constricted in their ability to respond. As the case of Captain Mario Negri showed, they had no authority over the composition of the control commissions. A former Italian consular agent who had returned to the Savoyard town of Modane in 1940, Negri's antiFrench propaganda campaign soon attracted the attention of the local authorities. ${ }^{65}$ Police spent several months monitoring his actions, uncovering not merely a catalogue of hostile conduct, but what they described as 'immoral' and 'louche' behaviour as well. ${ }^{66}$ Yet while Negri's activities were both a threat and an acute embarrassment, the French authorities found him extremely difficult to remove. It took months of negotiations at the highest levels of government for Vichy to secure his departure along with four other Italian functionaries. Even then, it was only after agreeing to dismiss nine French officials whom the CIAF had accused of harbouring anti-Italian sentiments. ${ }^{67}$

In significant part, the problem came back to the conflicting Italian and French interpretations of the armistice. The CIAF did not consider its actions to be limited in any way by the June 1940 terms. Vichy, however, adopted the position that the activities of the control commissions should be limited to the jurisdictions explicitly laid out in the agreement and that the armistice did not prejudice the defence of French national security. In towns such as Annecy, Toulon, and Marseille, as well as in North Africa, French police therefore routinely 
arrested Italian citizens for communicating intelligence to Italian officials. ${ }^{68}$ Matters came to a head in early March 1941, when police in Sfax arrested Professor Carlo Giodarno for passing information about the local economic situation to the Italian control commission. The arrest was the third of its kind involving Italian citizens working on behalf of the Italian armistice authorities in Tunisia in a matter of weeks and prompted a furious response from Turin. ${ }^{69}$ The CIAF denied that such activities amounted to espionage, insisting that the armistice terms gave them unrestricted rights to monitor all the military activities of the French state. ${ }^{70}$ It was an argument the DFCIA categorically rejected, accusing the Italians of deliberately conflating control and espionage. ${ }^{71}$ The activities of the control commissions were, Duplat insisted, conducted by official agents; the activities of those who were not part of these organizations constituted espionage and were therefore subject to French criminal law. ${ }^{72}$

From autumn 1940, French counterespionage sought to combat the threats to sovereignty and security from both the allies and the axis. Its work involved much more than merely arresting spies. Indeed, it later emerged that the attack against General Boselli in early 1941 was not all it had first appeared to be ${ }^{73}$ Far from being the work of hostile local residents, it had in fact been orchestrated by French counterespionage services as a means of intensifying the police presence and as a deterrent against Italian contacts with anti-colonial groups. ${ }^{74}$ Soon after the arrival of the Italian control commissions in 1940, the resident-general of Tunisia, Admiral Esteva, reported that officials had been seen meeting with Muslim notables in Gabès. ${ }^{75}$ They also made contact with former neo-Destour activists in Sfax and sought to foment trouble for the French colonial authorities in Morocco and Algeria. ${ }^{76}$ The Boselli attack was therefore intended, in the words of General Henri Navarre, to make it 'dangerous' for the Italian control commissions to engage in such activities. ${ }^{77}$ The incident also revealed the direct hand 
played by Weygand in counterespionage against the axis. In his memoirs, Weygand chose not to discuss the attack directly, merely claiming that the control commissions were sometimes sent anonymous threats to justify French security measures. ${ }^{78}$ When questioned at a National Assembly commission of enquiry in 1946, however, he reluctantly gave a little more detail, stating that 'mild attacks were organized against members of the control commission to convince them that they needed to be protected', and admitting that he had arranged for an Italian general to be given a 'good thrashing'. ${ }^{79}$

Weygand's role in counterespionage highlights the ambiguous positions of several senior Vichy figures not just between the axis and the allies, but between the Germans and the Italians. Many retained their old hostility towards Germany and were loath to see French sovereignty and security breached by the 'hereditary enemy'. In consequence, as Simon Kitson has highlighted, Vichy's policy of collaboration coexisted often problematically with its pursuit of Nazi spies as the French government sought to balance its ideological goals with its assertions of sovereignty. ${ }^{80}$ While Weygand was the most high-profile opponent of Berlin's encroachments upon French sovereignty, his antipathy towards Germany was shared by Huntziger. ${ }^{81}$ As a senior member of the government, however, Huntziger accepted the policy of collaboration and was careful not to endorse any measure that might cause wider diplomatic friction with Berlin. By contrast, when it came to Italy, the absence of any sustained policy of collaboration meant that there was no apparent inconsistency between counterespionage and Vichy's wider political agenda. While there were not the same traditions of animosity between France and Italy, the two countries having been allies in the First World War and having cooperated in military matters in the 1930s, the wounds caused by the Italian declaration of war remained fresh. ${ }^{82}$ Fuelled by a sense of betrayal and 
unhindered by collaboration, it might therefore seem logical to expect that French counterespionage should have targeted Italian spies more zealously than German spies.

In reality, however, French responses to axis espionage were multi-directional, operating at multiple levels and with multiple agendas. As a consequence, while some Italian spies were treated more severely than their German counterparts, others found themselves subjected to the conflicting approaches of the counterespionage services, police, colonial authorities, and Vichy. ${ }^{83}$ Indeed, counterespionage was never a straight-forward matter of simply defending French sovereignty. The example of Louis Glesaz, sentenced to death for spying for Italy in September 1940, was a case in point. Despite having been born in Paris and possessing a French passport, because his parents were Italian, he was classed as an Italian citizen under Italian law. ${ }^{84}$ The CIAF therefore demanded his release under Article 21 of the armistice. However, because the French authorities considered him to be a French citizen under French law, they refused. ${ }^{85}$ By contrast, in an earlier dispute over a convicted spy deemed to be a French citizen under French law and a German citizen under German law, Vichy had yielded to Berlin's demands for his release ${ }^{86}$ Faced with the charge of inconsistency, far from unbendingly asserting French sovereignty in the face of the CIAF, Duplat pragmatically proposed that Glesaz should be released to the Italian authorities. Such a gesture might, he suggested, help break the impasse over the return of French prisoners held in Italy. ${ }^{87}$ Huntziger, however, adopted a tougher stance, insisting that handing a French citizen to the Italian authorities would create a dangerous precedent. ${ }^{88}$ He therefore proposed that Glesaz should be pardoned instead. ${ }^{89}$ Laval was even more reluctant to be seen to yield ground on French sovereignty to the Italians, only accepting Huntziger's proposal on the condition that it should be used as political leverage with Rome. ${ }^{90}$ 
The conviction of a number of spies found to be working for the Italian authorities in Morocco cast particular light upon the inconsistencies in French responses to axis espionage and to axis breaches of Vichy's sovereignty. One of the most prominent cases centred upon the activities of Immormino, who was accused of passing French military secrets to the Italian authorities with the aid of his accomplice Biddisi. ${ }^{91}$ The two Italian citizens, who were implicated in several other espionage cases, were tried by a French military tribunal in 1942 and sentenced to death. ${ }^{92}$ However, whereas Vichy had unilaterally taken the decision not to execute German spies on 16 January 1942 in order to avoid political repercussions from Berlin, the decision had not been extended to those convicted of spying for Italy. ${ }^{93}$ It was only after Rome issued a series of urgent warnings that Vichy would face 'very serious consequences' if the death sentences were carried out that the French government finally relented. ${ }^{94}$

On the face of it, the Immormino and Biddisi case followed the conventional pattern of disputes between the French and Italian authorities over sovereignty. However, in the ambiguities it exposed over definitions of espionage and the nature of Franco-Italian relations, it was soon revealed to be significantly more complex. The French authorities presented it as a matter of defending sovereignty over judicial matters. By contrast, the Italian authorities sought not merely to refute the allegations, but to allege that the whole case had been a setup along the lines of the false accusations levelled against Captain Alfred Dreyfus in $1894 .^{95}$ The head of the CIAF, General Arturo Vacca Maggiolini, even went so far as to implicate the Vichy government, asserting that a French police officer involved in the case had been sentenced to death merely to give the conspiracy greater credibility. ${ }^{96}$ While he categorically denied the allegations, Duplat privately hinted that they had the ring of truth. ${ }^{97}$ Visiting Rome's counterespionage services, he had been met with an absolute insistence that 
Immormino, Biddisi, and the other accused were unknown to Italian intelligence and had never been in their pay. ${ }^{98}$ Moreover, the Boselli incident had shown that French counterespionage services were willing to use any methods necessary to achieve their goals. The doubts expressed by Duplat also reflected the fact that French armistice officials were usually kept in the dark about covert operations. Indeed, they sometimes had to check that suspected Italian spies were not in fact working for their own intelligence services. ${ }^{99}$

The disputes over the activities of Italian citizens purporting to be working for the control commissions exposed the divergent French approaches not only towards espionage but towards the defence of sovereignty more broadly. Between the different layers of government and administration lay distinct and often conflicting political agendas and priorities. As Vichy sought to pursue its agenda, the French colonial authorities carved out a particular role for themselves as defiant opponents of Axis intervention and any policy that sought to impose it. ${ }^{100}$ Such was the case in the summer of 1941 when Huntziger intervened to halt the arrest of Italian citizens found disseminating propaganda in Tunisia. Following warnings that the measures taken by authorities in North Africa were overly zealous and damaging efforts to improve relations with Rome, Huntziger complained to Darlan that they had 'not taken sufficient account of the consequences of actions based on a too rigid interpretation of [the armistice] texts'. ${ }^{101}$ While he insisted that taking a more conciliatory approach would not damage efforts to protect French sovereignty, Huntziger demanded that French officials in Tunisia 'temper their firmness with tact'. ${ }^{102}$ Indeed, he argued, it was in the 'national interest' that police should avoid subjecting Italian citizens to 'vexatious measures'. ${ }^{103}$

The normal French response to the dissemination of Italian propaganda was simply to arrest those responsible. After all, to have a foreign power spreading hostile material was not 
merely a breach of French sovereignty but a threat to national security and to Vichy's political authority as well. In North Africa and the Middle East, Fascist propaganda had been stirring up problems for the French colonial authorities since the mid-1930s. Through Arabiclanguage broadcasts on Radio Bari, Rome managed to promote Fascist ideas, divide communities, and encourage hostility to French rule. ${ }^{104}$ The rise of anti-colonial movements provided fertile ground for such propaganda. ${ }^{105}$ A report commissioned by Vichy on the 'dislocation of the French colonial empire' in early September 1940 painted a grim picture of French vulnerability. ${ }^{106}$ In Syria and Lebanon, the damage to French prestige after the defeat was significant enough to fuel widespread disorder and discontent. ${ }^{107}$

Huntziger's call for less severe measures was therefore a major policy reversal. Significantly, however, it came in response to the advice he had received from the DFCIA. Despite expressing his concerns over the CIAF's attempts to extend Article 21 on the liberation of Italian prisoners, General Parisot advised acceding to Italian requests for the release of those arrested in Tunisia. On the one hand he argued that it would be 'difficult' to have to tell Aaxis officials that any Italian or German propaganda activities would be punished in such a way, proposing a show of 'goodwill' towards the Italians instead. ${ }^{108}$ On the other, however, Parisot argued that a modus vivendi was necessary to enable French officials to deal with the 'more important' matters in play. ${ }^{109}$ While he did not specify what those matters were, a day earlier Vacca Maggiolini had warned that if concessions on the prisoners' release were not forthcoming, French citizens living in the Italian zone of occupation would face significant repercussions. ${ }^{110}$

The records of the DFCIA show that around the time of this exchange, the growing threats to French sovereignty in the Italian zone of occupation were among the main challenges facing 
officials. The scale of Rome's ambitions had been immediately apparent in Mussolini's 'Proclamation Concerning Administrative and Judicial Organization in the Occupied Territories' of 30 July 1940. The Fascist government unilaterally seized control over civil, financial, and judicial affairs and replaced French law with Italian law. ${ }^{111}$ In late July 1941 , the head of the interior section of the DFCIA, Marius Sarraz-Bournet, issued a stark report on the consequences of such actions, concluding that Italian actions were 'designed to replace French sovereignty with Italian sovereignty.' ${ }^{112}$ Council employees as well as teachers, police officers, and firefighters had been prevented from resuming their posts, while thousands of French citizens were refused permission to return as well. ${ }^{113}$ Schools had been forced to adopt the Italian curriculum, public buildings had been renamed, and road signs had been replaced with Italian equivalents. ${ }^{114}$

With the defence of territorial integrity lying at the heart of its claims of legitimacy, Vichy was determined not to cede sovereignty. ${ }^{115}$ Developments in the Italian zone of occupation echoed Berlin's de facto annexation of Alsace-Lorraine in which the German authorities replaced the French language, education, and legal system, and sought to engineer a majority German population by expelling 270,000 French citizens. ${ }^{116}$ However, while fears of endangering collaboration with Berlin constrained French opposition to German actions, such considerations did not come into play with the Italians. The DFCIA mounted a vigorous legal defence against Italian measures, going further than any of the DFCAA's objections on Alsace-Lorraine, rejecting not just the attempts to subvert French sovereignty but refuting Italy's right even to occupy the areas under question. ${ }^{117}$ Thus Huntziger's calls for a lenient response to Fascist propaganda activities in North Africa might have seemed like a loss of sovereignty in the colonial empire, but it was to avoid jeopardizing efforts to prevent a much greater loss of sovereignty in the Italian zone of occupation. 


\section{IV}

After the expansion of the Italian zone of occupation in November 1942, the conflicts between French, Italian, and German policies on the Jews gave rise to some of the most significant and consequential battles over sovereignty. ${ }^{118}$ Prior to occupation, however, antiSemitic legislation and the roundup of Jews prompted some of the most significant interventions by the CIAF into areas that Vichy considered domains of French authority. Vichy's attempts to preserve sovereignty by not merely implementing Nazi policies on the persecution of the Jews but presenting them as its own have been at the heart of a wider debate over the moral consequences of the French government's actions. ${ }^{119}$ Yet it is in the decision to collude with the Germans rather than support Italian efforts to thwart the deportation of the Jews that the hollowness of Vichy's claims to have shielded France from Nazi brutalities becomes particularly clear. ${ }^{120}$ While historians continue to debate Italian motivations, it remains the case that French officials' attempts to defend the authority of the state and the ideological goals of the Vichy government led them to oppose the protective measures introduced by the Italians. ${ }^{121}$

While the desire to maintain administrative sovereignty lay at the heart of Vichy's rationale for implementing Nazi demands, French responses to Italian interventions were driven by concerns over territorial sovereignty. To have acquiesced to Italian actions would have meant yielding authority over territories the Italian Fascists had long coveted. Italian intervention risked not only damaging the authority of the Vichy government but fuelling its unpopularity as well. The Nazi occupation of northern France led many Jews to flee south to escape 
persecution. However, by the summer of 1942 the aggravation of Vichy's measures saw roundups being extended to the southern zone. Around five hundred Jews were arrested in Nice on 26 August 1942, against widespread opposition from residents. ${ }^{122}$ Some local officials reported that communities supported the government's actions but many others described a growing disquiet at measures that separated families and went against French humanitarian traditions. ${ }^{123}$ In response, as Italian officials became aware of the mounting severity of the French policies, so they became increasingly determined to intervene to protect the rights and property of Italian Jews. ${ }^{124}$ The Italian government did not oppose French racial laws in principle, being not entirely dissimilar to those introduced by the Fascist regime in 1938. It was rather that the Italian foreign ministry suspected that the policies Vichy had introduced under the guise of a racial agenda were really designed to damage the position of Italian communities across the Mediterranean basin. ${ }^{125}$

The significance that Vichy ascribed to retaining control over the French colonial empire combined with long-running imperial rivalries with Italy gave the dispute over sovereignty in the application of anti-Semitic measures a distinct character in North Africa. Policies to restrict the rights of Jews or to seize Jewish economic assets were an integral part of Vichy's ideological project as it sought to transpose its domestic agenda onto the French colonial empire. ${ }^{126}$ However, in implementing such measures, the French colonial authorities also had to balance the imperatives of ideology with the pragmatic need to avoid giving Rome a pretext for intervention. Italian officials complained that the relatively high levels of property ownership among Italian Jews meant that the seizure of Jewish assets would tip the economic balance of power decisively in the French favour. ${ }^{127}$ In so doing, they would damage Italy's interests and prestige in the protectorate, leaving its position weaker than it had been before the French defeat. Esteva accused Italian officials of 'hypocrisy' by defending the Jews in 
contravention of their own racial laws and in defiance of Berlin simply to discredit French colonial authority. ${ }^{128}$ However, the French colonial authorities conceded that Jews would be permitted to continue to hold public office within Jewish organizations and delayed the implementation of legislation concerning the seizure of property. ${ }^{129}$ The measures meant yielding to the Italians, but they were the consequence of a broader strategic calculation that a relatively minor concession on sovereignty would help preserve French authority against greater threats resulting from tensions with Rome.

This article has suggested that the defence of French sovereignty against Italian threats did not result in collaboration; but nor was it a simple story of unmitigated 'resistance'. Vichy's responses to Italian actions took a different path to its responses to German actions. Mussolini's government was not so much seeking to impose its policies on the areas under the jurisdiction of the CIAF as to preserve its prestige, work towards future territorial annexation, and ensure that the status of France was permanently diminished. In turn, unlike with Germany, it was wounded pride at the Italian claims of victory that drove Vichy's determination not to cede its authority. However, because French sovereignty was politically defined rather than set out in the armistice terms, its preservation was a political act that needed to be undertaken by political actors. The problem was that because Vichy's relations with Italy were primarily conducted through the CIAF, rather than meetings between members of the government as was the case with Germany, the scope for actively defending sovereignty was more limited despite the political parameters being less constrained. 
Vichy did not treat its dealings with the two Axis partners in isolation from one another. French officials often compared German and Italian policies and saw the control commissions' attempts to extend their authority as elements of the same broader crisis. Nevertheless, Vichy conceived of sovereignty as divisible and comprising multiple dimensions. It therefore adopted measures that varied across areas of policy and in response to differing levels of threat. For Vichy, the defence of sovereignty against Italian actions was a zero-sum game in which it was acceptable to endure minor losses so long as Italy lost out as well.

The different ways in which Vichy responded to similar Italian and German threats has wider implications for historians' understanding of the relationship between the defence of sovereignty and collaboration. The Italian dimension of French policy shows that the defence of sovereignty did not necessarily lead to further collaboration and there was not an inevitable spiral drawing Vichy into further complicity with the axis. The case of Italy rather highlights the significance of Vichy's choices and agency. Vichy's notion that defending sovereignty required further collaboration was based on a delusion about German intentions which was not replicated in its perceptions of Italian intentions, towards which it had a more realistic, pragmatic assessment. French dealings with the Italian authorities show that without the delusion of collaboration, Vichy was less likely to make concessions to defend sovereignty. It was therefore the dogged pursuit of collaboration rather than the defence of sovereignty that proved the greater liability for Vichy. 
${ }^{1}$ See in particular, R. O. Paxton, Vichy France: Old Guard and New Order, 1940-1944 (New York, 1972); S. Hoffmann, 'Collaborationism in France during World War II', Journal of Modern History, 40 (1968), 375-95; P. Burrin, Living with Defeat: France Under the German Occupation, 1940-1944 trans. J. Lloyd (London, 1996); S. Kitson, Vichy et la chasse aux espions nazis 1940-1942: Complexités de la politique de collaboration (Paris, 2005).

${ }^{2}$ M. O. Baruch, Le régime de Vichy 1940-1944 (Paris, 2017), 52.

${ }^{3}$ Paxton, Vichy France, 357-83.

${ }^{4}$ R. Frank, 'Vichy et le monde, le monde et Vichy: perceptions géopolitiques et idéologiques', in Le régime de Vichy et les Français, eds. J.-P. Azéma and F. Bédarida (Paris, 1992), 99-121, 103.

${ }^{5}$ Burrin, Living with Defeat, 1-4.

${ }^{6}$ M-O. Baruch, Servir l'Etat français. L'administration en France de 1940 à 1944 (Paris, 1997), 77, 373-4, 583.

${ }^{7}$ Délégation Française à la Commission Allemande d'Armistice (DFCAA), Délégation Française à la Commission Italienne d'Armistice (DFCIA).

${ }^{8}$ M. Vernoux, Wiesbaden 1940-1944 (Paris, 1954), 13.

${ }^{9}$ R. Rainero, 'Une résistance silencieuse: La délégation française auprès de la Commission Italienne d'Armistice avec la France (Turin, 27 juin 1940 - 8 septembre 1943)', Guerres mondiales et conflits contemporains, 251 (2013), 115-41, 121.

${ }^{10}$ Vernoux, Wiesbaden, 273; Rainero, 'Une résistance silencieuse', 116.

${ }^{11}$ Paxton, Vichy France, 374.

${ }^{12}$ Ibid, 381. 
${ }^{13}$ Minutes of negotiations at Compiègne, 22 June 1940, D[ocuments] on G[erman]

F[oreign] P[olicy], series D, vol. IX (London, 1956), 668; M[inistère des] A[ffaires]

E[trangères] Papiers Baudouin 1, Council of Ministers, 22 June 1940, 1.30am.

${ }^{14}$ J.-F. Charles-Roux, Cinq mois tragiques aux affaires étrangères, 21 mai-1er novembre 1940 (Paris, 1949), 101.

${ }^{15}$ Armistice text in R. Rainero, La commission italienne d'armistice avec la France. Les rapports entre la France de Vichy et l'Italie de Mussolini (10 juin 1940 - 8 septembre 1943)

(Paris, 1995), 378-82.

${ }^{16}$ Baruch, Servir l'Etat français, 65.

${ }^{17}$ Rainero, 'Résistance silencieuse', 51-52.

${ }^{18}$ A[rchives] N[ationales] AN AJ41 2299, Intentions of Italy, 13 Aug. 1940.

${ }^{19}$ MAE Papiers Charles-Roux 3, Handwritten note, no date.

${ }^{20}$ MAE 9GMII 215, Note by Pierre Bressy, 17 Nov. 1942.

${ }^{21}$ K. Varley, 'Entangled Enemies: Vichy, Italy and Collaboration', in France in an Era of

Global War, 1914-1945: Occupation, Politics, Empire and Entanglements, eds. A. Carrol and L. Broch (Basingstoke, 2014), 152-170.

${ }^{22}$ Baruch, Servir l'Etat français, 366-69.

${ }^{23}$ M. Thomas, The French Empire at War 1940-45 (Manchester, 2007), 71.

${ }^{24}$ See D. Rodogno, Fascism's European Empire: Italian Occupation During the Second World War, trans. Adrian Belton (Cambridge, 2006).

${ }^{25}$ R. O. Paxton, Parades and Politics at Vichy: The French Officer Corps under Marshal Pétain (Princeton, 1966), 113.

${ }^{26}$ Rainero, 'Résistance silencieuse', 127-8.

${ }^{27}$ AN AJ41 2153, DFCIA, 28 June 1940 - 31 Dec. 1942. 
${ }^{28}$ Meeting between Huntziger and von Stülpnagel, 12 Sept. 1940, La D[élégation]

F[rançaise auprès de la] C[ommission] A[llemande d']A[rmistice]. Recueil de documents

publiés par le gouvernement français, vol. 1 (Paris, 1947), 274-80.

${ }^{29}$ Paxton, Vichy France, 68.

${ }^{30}$ AN AJ41 2235, DFCIA History of army sub-delegation after 28 June 1940.

${ }^{31}$ Rainero, 'Résistance silencieuse', 127.

${ }^{32}$ AN AJ41 2149, Huntziger to Badoglio, 17 Sept. 1940.

${ }^{33}$ Huntziger to von Stulpnagel, 5 Sept. 1940, reproduced in Vernoux, 65; Meeting between

Huntziger and von Stülpnagel, 12 Sept. 1940, DFCAA, vol. 1, 274-80.

${ }^{34}$ AN AJ41 2297, Badoglio to Huntziger, 22 Sept. 1940.

${ }^{35}$ Ibid.

${ }^{36}$ Ibid.

${ }^{37}$ AN AJ41 2149, Huntziger to Badoglio, 17 Sept. 1940.

${ }^{38}$ Paxton, Vichy France, 82.

${ }^{39}$ Murphy to Secretary of State, 9 Dec. 1940, Foreign Relations of the United States

Diplomatic Papers, 1940, General and Europe, vol. II (Washington, 1957), 415.

${ }^{40}$ Abetz to Foreign Ministry, 11 Dec. 1940, DFGP, series D, vol. XI (London, 1961), 839-40.

${ }^{41}$ Paxton, Parades and Politics, 113.

${ }^{42}$ Representative of Foreign Minister with German Armistice Commission to Foreign

Minister, 5 Oct. 1940, DGFP, series D, vol. XI, 262-4; Representative of Foreign Minister with German Armistice Commission to Foreign Minister, 12 Oct. 1940, DGFP, series D, vol. XI, 290.

${ }^{43}$ Doyen to von Stülpnagel, 15 Jan. 1941. DFCAA, vol. III, (Paris, 1952), 475-6.

${ }^{44}$ Meeting between Doyen and Vogl, 15 Feb. 1941, DFCAA, vol, IV (Paris, 1957), 106.

${ }^{45}$ Ibid, 111. 
${ }^{46}$ Ibid, 107.

${ }^{47}$ Vernoux, Wiesbaden, 77.

${ }^{48}$ Military and political sub-commission meetings, 30 June -6 July 1941; 19 Jan. 1941-21

July 1941, DFCAA, vol. IV, 600, 614.

${ }^{49}$ Vernoux, Wiesbaden, 55.

${ }^{50}$ AN AJ41 2313, Duplat to Grossi, 17 Apr. 1941.

${ }^{51}$ AN AJ41 2313, Weygand to Huntziger, 14 Jan. 1941.

${ }^{52}$ AN AJ41 65, Weygand to Huntziger, 15 May 1941.

${ }^{53}$ AN AJ41 2297, activity of former Italian consuls in France, 7 Aug. 1940; AN AJ41 2313, report by Captain Perriaux, 30 July 1940; AN AJ41 2297, meeting between Duplat and Pintor, 29 Aug. 1940.

${ }^{54}$ MAE 9GMII 189, telegram from Noguès, 7 Sept. 1940; Baudouin to Huntziger, 7 Sept. 1940; Foreign Ministry to War Ministry, 6 Jan. 1941.

${ }^{55}$ AN AJ41 2297, Capitain Renon to divisional commander for Corsica, 14 July 1940; AN AJ41 2335, Vaucelles to Huntziger, 12 Feb. 1941.

${ }^{56}$ MAE 9GMII 189, Huntziger to Flandin, 16 Jan. 1941.

${ }^{57}$ MAE 9GMII 187, report by surveillance commissioner for Nice, 12 Oct. 1940; AN AJ41 2150, non-military activity of industrial control delegations, 4 Aug. 1941; AN AJ41 2313, letter from of Prefect of Basses-Alpes to Peyrouton, 10 Oct. 1940.

${ }^{58}$ AN AJ41 2313, Huntziger to Peyrouton and Baudouin, 23 Oct. 1940; AN AJ41 2313, Prefect of Corsica to Darlan, 30 Apr. 1941; MAE 9GMII 187, report on Italian control commission at Marseille, 9 Aug. 1940; AJ41 2313, Prefect of Haute-Savoie to Peyrouton, 11 Nov. 1940; AN AJ41 2313, Prefect of Basses-Alpes to Peyrouton, 17 Feb. 1941. ${ }^{59}$ AN AJ41 2313, Police chief Bouchede to prefect, 24 Sept. 1940; AN AJ41 2151, aidemémoire for Duplat, 23 March 1942. 
${ }^{60} \mathrm{~A}[\mathrm{rchives}] \mathrm{D}$ [épartementales des] A[lpes]-M[aritimes], 616W223, anti-national propaganda; A[rchives] D[épartementales de la] S[avoie], 1382W40, census, Dec. 1939; AN AJ41 2313, Italians in Isère, 6 Dec. 1940; R. H. Rainero, 'Les Italiens en Afrique du Nord', in Les Italiens en France de 1914 à 1940, ed. P. Milza (Rome, 1986), 745-60, 759.

${ }^{61}$ AN AJ41 2313, report by Captain Perriaux, 1 Aug. 1940.

${ }^{62}$ AN F1cIII 1137, Prefect of Alpes-Maritimes to Peyrouton, 18 Nov. 1940.

${ }^{63}$ AN AJ41 2313, Huntziger to general commander for Avignon, 24 Feb. 1941.

${ }^{64}$ AN AJ41 2313, demarches to French subjects by armistice commissions, 16 Sept. 1941; Archives Départementales du Corse du Sud, 6W21, armistice service liaison to Italian control commission at Ajaccio, 22 Nov. 1941; P. Paillole, Fighting the Nazis: French Military Intelligence and Counterintelligence 1935-1945 (New York, 2002), 273.

${ }^{65}$ AN AJ41 489, Special police commissioner to Prefect of Savoie, 11 Nov. 1941; AN AJ41 2313, Italians in Savoie 15 Dec. 1940; AN AJ41 489, Belin to Darlan, 30 Dec. 1941. ${ }^{66}$ ADS 1382W40, Special police divisional commissioner to Sarraz-Bournet, 20 Feb. 1941; AN AJ41 2314, Report, 16-26 March 1941; AJ41 2150, Duplat to Huntziger, 17 Apr. 1941. ${ }^{67}$ AN AJ41 489, Darlan to War Ministry, 25 Oct. 1941; AN AJ41 2314, Duplat to Darlan, 25 Oct. 1941; AJ41 2149, DFCIA to Vacca Maggiolini, 22 Nov. 1941.

${ }^{68}$ AN AJ41 2308, Duplat to Darlan, 4 Feb. 1942; AN AJ41 2308, Darlan to Duplat, 12 March 1942; AN AJ41 2308, Laval to Duplat, 20 May 1942.

${ }^{69}$ AN AJ41 2317, Grossi to Duplat, 16 March 1941.

${ }^{70}$ AN AJ41 2149, Duplat to Laval, 12 May 1942; AN AJ41 2335, Vacca Maggiolini to Duplat, 3 July 1942; AN AJ41 2335, Duplat to Vacca Maggiolini, 24 July 1942.

${ }^{71}$ AN AJ41 2151, Dulat to Laval, 25 July 1942

72 AN AJ41 2335, Duplat to Vacca Maggiolini, 24 July 1942. 
${ }^{73}$ MAE 9GMII 189, Weygand to Huntziger, 14 Jan. 1941; AN AJ41 2297, Grossi to Duplat, 25 Jan. 1941.

${ }^{74}$ Paillole, Fighting the Nazis, 273.

${ }^{75}$ MAE Papiers Baudouin 9, telegram from Esteva, 19 Sept. 1940.

${ }^{76}$ MAE 8GMII 26, note for minister, 23 Aug. 1940; MAE Papiers Baudouin 9, telegram from Esteva, 9 Oct. 1940; MAE 9GMII 189, Information, 14 Oct. 1940; MAE 8GMII 26, telegram from Laffond, 6 June 1941.

77 'Un aspect de la résistance en Afrique du Nord, récit par Général Henri Navarre', http://www.aassdn.org/xldd11392.htm.

${ }^{78}$ M. Weygand, Recalled to Service: The Memoirs of General Maxime Weygand trans. E. W. Dickes (London, 1952), 315.

${ }^{79}$ Assemblée Nationale, Commission d'enquête sur les événements de 1933 à 1945, vol. 6 (Paris, 1951), 1661.

${ }^{80}$ Kitson, Vichy et la chasse, 192-201.

${ }^{81}$ Ibid, 174, 184, 185.

${ }^{82}$ W. I. Shorrock, From Ally to Enemy: The Enigma of Fascist Italy in French Diplomacy, 1920-1940 (London, 1988), 284.

${ }^{83}$ AN AJ41 2151, Vacca Maggiolini to Duplat, 15 May 1942; AJ41 2312, Duplat to Laval, 19 May 1942.

${ }^{84}$ AN AJ41 2330, note for DSA, 26 Oct. 1940.

${ }^{85}$ AN AJ41 2330, Pintor to Duplat, 30 Nov. 1940; AN AJ41 2330, Huntziger to Alibert, 23 Dec. 1940.

${ }^{86}$ AN AJ41 2330, Huntziger to Laval, 10 Dec. 1940.

${ }^{87}$ AN AJ41 2330, Duplat to Pintor, 27 Oct. 1940; AN AJ41 2330, Duplat to Huntziger, 3 Dec. 1940. 
${ }^{88}$ AN AJ41 2330, Huntziger to Alibert, 23 Dec. 1940.

${ }^{89}$ MAE 2GMII 288, Huntziger to Laval, 10 Dec. 1940.

${ }^{90}$ MAE 2GMII 288, Laval to Huntziger, 12 Dec. 1940.

${ }^{91}$ AN AJ41 2335, Duplat to Vacca Maggiolini, 7 July 1942.

${ }^{92}$ AN AJ41 2335, Duplat to Vacca Maggiolini, 24 July 1942.

${ }^{93}$ Kitson, Vichy et la chasse, 162.

${ }^{94}$ MAE 2GMII 288, telegram, 13 May 1942; AN AJ41 2151, Vacca Maggiolini to Duplat, 15 May 1942; MAE 2GMII 288, Sanguinetti to Laval, 27 May 1942; AN AJ41 2335, Gamaleri to Duplat, 18 June 1942; AN AJ41 2308, Laval to Barthélemy, 23 June 1942.

${ }^{95}$ AN AJ41 2149, Duplat to Laval, 12 May 1942; AN AJ41 2312, Duplat to Laval, 4 June 1942; AN AJ41 2151, Duplat to Laval, 27 June 1942; AN AJ41 2335, Vacca Maggiolini to Duplat, 3 July 1942; AN AJ41 2335, Parisot to Laval, 16 July 1942; AN AJ41 2151, Duplat to Laval, 25 July 1942.

96 AN AJ41 2312, Duplat to Laval, 4 June 1942.

${ }^{97}$ AN AJ41 2151, Duplat to Laval, 27 June 1942.

${ }^{98}$ AN AJ41 2312, Duplat to Laval, 4 June 1942.

${ }^{99}$ MAE 2GMII 288, Huntziger to Darlan, 8 Sept. 1941.

${ }^{100}$ MAE 9GMII 275, Gross to Huntziger, no date; MAE 9GMII 275, DSA to Rochat, 8 Jan. 1942.

101 AN AJ41 2317, Huntziger to Darlan, 18 Aug. 1941.

102 Ibid.

${ }^{103}$ Ibid.

${ }^{104}$ MAE 9GMII 275, telegram from Esteva, 29 July 1940; MAE 9GMII 275, Weygand to Duplat, 27 Aug. 1940; AN AJ41 478, Laval to Duplat, 23 Sept. 1942. 
${ }^{105}$ See C. Levisse-Touzé, L'Afrique du Nord dans la guerre (Paris, 1998); R. H. Rainero, La politique arabe de Mussolini pendant la seconde guerre mondiale trans. J. L.Riccioli (Paris, 2006).

${ }^{106}$ AN F60 309, risks of dislocation of the French empire in Africa, 6 Sept. 1940.

${ }^{107}$ AN AJ41 2297, Baudouin to Huntziger, 11 Oct. 1940.

108 AN AJ41 2317, Parisot to Huntziger, 30 July 1941.

${ }^{109}$ Ibid.

${ }^{110}$ AN AJ41 2317, Vacca Maggiolini to Duplat, 29 July 1941.

${ }^{111}$ ADS 1382W39, Report for Duplat, 23 July 1940; AN AJ41 2302, Duplat to Huntziger, 28 Sept. 1940; AN AJ41 2304, Huntziger to Duplat, 7 Jan. 1941.

${ }^{112}$ ADS 1382W39, Report for Duplat, 23 July 1941.

113 AN AJ41 2302, Occupation of Menton, 26 July 1941; ADAM 30W57, Marcel Rauch to mayor of Nice, 17 March 1941; J-L. Panicacci, L'Occupation italienne. Sud-est de la France, juin 1940-septembre 1943 (Rennes, 2010), 46-69; E. Sica, Mussolini's Army in the Riviera: Italy's Occupation of France (Urbana, 2016), 55-69.

114 AN AJ41 431, Duplat to Vacca Maggiolini, 5 Aug. 1941.

115 AN AJ41 431, Weygand to Duplat, 9 Aug. 1940; AN AJ41 431, Baudouin to Weygand, 16 Aug. 1940.

${ }^{116}$ On the experiences of Alsace, see B. Le Marec and G. Le Marec, L'Alsace dans la guerre, 1939-1945 (Le Coteau, 1988).

${ }^{117}$ AN AJ41 2304, Duplat to Vacca Maggiolini, 18 May 1942; AN AJ41 2151, Note by juridical section, 10 June 1942.

${ }^{118}$ See D. Carpi, Between Mussolini and Hitler: The Jews and the Italian Authorities in France and Tunisia (Hanover, 1994).

${ }^{119}$ L. Joly, L'Etat contre les juifs. Vichy, les Nazis et la persécution antisémite (Paris, 2018). 
${ }^{120}$ See, in particular, M. Marrus and R. O. Paxton, Vichy France and the Jews (Stanford, 1981); R. Poznanski, Les Juifs en France pendant la Seconde Guerre mondiale (Paris, 2005);

S. Zuccotti, The Holocaust, the French, and the Jews (New York, 1993).

${ }^{121}$ D. Rodogno, 'La politique des occupants italiens à l'égard des Juifs en France métropolitaine. Humanisme ou pragmatisme?', Vingtième siècle. Revue d'histoire, 93 (2007), 63-77.

${ }^{122}$ Sica, Mussolini's Army, 165.

${ }^{123} \mathrm{~A}$ [rchives] D[épartementales de la] H[aute]-S[avoie], 8W10, sub-prefecture of Bonneville monthly report, 30 March 1941; ADHS 8W11, sub-prefect of Bonneville to Prefect of HauteSavoie, 25 Aug. 1942; ADHS 14W13, Prefect of Haute-Savoie to regional prefect, 3 Oct.

1942; AN AJ41 2307, Renseignements Généraux of Modane, 24 Sept. 1942.

${ }^{124}$ Carpi, Between Mussolini and Hitler, 33, 72.

${ }^{125}$ Ibid, 49-50.

${ }^{126}$ E. Jennings, Vichy in the Tropics: Pétain's National Revolution in Madagascar,

Guadeloupe, and Indochina, 1940-1944 (Stanford, 2001), 2.

${ }^{127}$ T. Peterson, 'The "Jewish question" and the "Italian peril": Vichy, Italy and the Jews of Tunisia, 1940-2', Journal of Contemporary History, 50 (2015), 234-58, 237.

${ }^{128}$ MAE 9GMII 276, Esteva to Darlan, 27 Feb. 1942; MAE 9GMII 276, Esteva to Darlan, 27 March 1942.

${ }^{129}$ Peterson, "The "Jewish question"”, 251. 